\title{
Over view on small pelagic fish preservation outlook and nutrient intake in Eritrean Red Sea: Review
}

\begin{abstract}
Fish are one of the most important foods in human diet because of its high nutritional quality. They are a rich source of two important n-3 PUFAs: eicosapentaenoic acid (EPA) and docosahexaenoic acid (DHA). Which can prevent many types of diseases. Consuming small pelagic fish whole could contribute significantly to reducing the level of micronutrient and protein malnutrition. Small pelagic fish products are more affordable and could therefore meet the needs of every group of consumers. Preservation could secure availability of fish and its products throughout a year. Preservation of fish by drying and processing into value added food products can contribute greatly to extend the period of fish availability for all classes consumers to be a source of animal protein. Sustain available of marine resource has high contribution towards nutritional intake and health of consumers. Despite the huge resource of Eritrean Red Sea $(80,000$ metric tons per year), the utilization is very low $(0.5-1 \mathrm{~kg}$ per person per year) and these problems have great implications on the efficient and effective utilization of the resources. The present work reviewing the possibility of increasing fish consumption rate being highlighted on perspectives of small pelagic fish preservation, nutritional and healthy aspects of fish, value added products, as well as history and exploitation of Eritrean Red Sea.
\end{abstract}

Keywords: preservation, sensory attributes, nutrition and health, value added products, maximum sustainable yield
Volume 6 Issue 5 - 2018

\author{
Bereket Abraha, ${ }^{1,2}$ Melake Samuel, ${ }^{1,3}$ \\ Abdu Mahmud, ${ }^{1,2}$ Negasi Tsighe, ${ }^{2}$ Mogos \\ Grimatsion, ${ }^{1,2}$ Madhu Babu Kasimala ${ }^{2}$ \\ 'State Key Laboratory of Food Science and Technology, Jiangnan \\ University, China \\ ${ }^{2}$ Department of Marine Food and Biotechnology, Massawa \\ College of Marine Science and Technology, Eritrea \\ ${ }^{3}$ Food and Commodity Quality Management Department, Russia \\ State Agarian University, Russia
}

\begin{abstract}
Correspondence: Bereket Abraha, State Key Laboratory of Food Science and Technology, School of Food Science and Technology, Collaborative Innovation Center of Food Safety and Quality Control in Jiangsu Province, Jiangnan University, Wuxi, Jiangsu $214 \mid 22$, China, Tel +86-|86- |667226, Fax +86-5 I085809610, Email beraketmft@yahoo.com
\end{abstract}

Received: September 30, 2018| Published: October 10, 2018

\section{Introduction}

Sufficiencies in nutrient intake not only, in quantity but also in quality are most important determinants of health of every country. Eritrea is a country located in North East Africa, go through nutrition shifting and is facing the dual burden of undernourishment, that is problem of under-nutrition and micronutrient insufficiencies. ${ }^{1}$ Fish are consumed as food in virtually all regions around the world. Fish has been an important source of protein and other nutrients for humans from time immemorial which can address this problem unswervingly. ${ }^{2}$ $\mathrm{IFAD}^{3}$ has reported that, Eritrean Read Sea has ample fish resources, however fish consumption is not satisfactory $(1 / 2-1 \mathrm{~kg} /$ person/year).

Eritrea has a continental shelf of about $52,000 \mathrm{~km}^{2}$ in the $0-200 \mathrm{~m}$ depth interval of the Red Sea. The total coastline runs to some $1,720 \mathrm{~km}$, comprising $1,155 \mathrm{~km}$ along the continental shore and roughly $565 \mathrm{~km}$ around the numerous islands of the continental shelf. ${ }^{1}$ About $25 \%$ of the shelf is occupied by the Dahlak archipelago plateau, in the $0-35 \mathrm{~m}$ depth interval. Its average width is variable, being widest $(120 \mathrm{~km})$ at the latitude of the Dahlaks themselves and quite narrow to the north $(15 \mathrm{~km})$ and south $(30 \mathrm{~km})$ of the archipelago. ${ }^{1,4}$ Eritrean Red Sea has 360 islands with a coastline of $2,234 \mathrm{~km}$ in length. ${ }^{1}$ Scholars have been reported and highlighted that, Eritrean Red Sea is a virgin and has various aquatic resources due to the availability of unexploited potential of natural resources. ${ }^{3}$ It is highly productive which has 1000 species of fish and 220 species of coral reefs. Groupers, snappers, emperors, lizardfish, breams, jacks, trevallies, mackerel s, tunas, sharks, sardines and anchovies are some of the commercially valuable fish ${ }^{1}$. It was suggested that, such huge fishery resources could contribute significant role in food security. ${ }^{4}$ In 1966-1967, the maximum level at which aquatic resource of Eritrean
Red Sea was very active and estimated 80,000 metric tons/year and small fish like anchovy, sardine, mackerel and soon have been anticipated around 50,000 metric tons in a year. ${ }^{4,5}$ Later in 1972, due to long war of independence fishery activity was totally collapsed. After independence capture production was recovered and was estimated 4000 tons in $2013 .{ }^{1}$ More than $60 \%$ of the maximum sustainble yield of Eritrean Red sea is covered by small pelagic fish, however, their utilization is minimal. More-over, these fish are largely incorporated into animal feed rather than human use. ${ }^{6}$

Fish is a food of excellent nutritional value, providing high quality protein, essential fatty and a wide variety of vitamins and minerals compared to other animals. ${ }^{7}$ Though fish is highly perishable, preservation of fish by drying and processing into value added food products can contribute significantly to lengthen the period of fish accessibility for all classes of people to be a source of animal protein and minerals such as calcium and phosphorous. Small fish like anchovies, sardines and herring eaten as a whole are very rich in calcium compared with other animal source foods and large fish species. Improving nutrient intakes through increasing the intake of nutrient-dense small fish is one way of improving nutritional status. ${ }^{8}$ The current review work focused on reviewing scientific literatures on the quality of small pelagic fish preservation, fish nutrient intake, health aspects and the importance of fish in human nutrition and how during seasons of surplus small dried fish with bones can be utilized in adding value to starch based foods.

\section{Fish consumption rate}

Globalization, industrialization, economic growth and transition in lifestyle patterns has greatly influenced the choice of food and the 
food consumption pattern of all age groups in developing countries like Eritrea. ${ }^{3,5}$ Even though the country has huge aquatic resources, but the consumption rate is projected at $0.5-1 \mathrm{~kg} /$ person in a year. ${ }^{3}$ It is a fact that, the few amount resource which is exploited suffers different problems due to the lack of proper preservation technology, which have an effect on the quality and safety. ${ }^{6}$ Moreover small pelagic fish, such as anchovies, and sardine are processed into fishmeal, however the consumers not only those who are leaving very far from the coast area of the sea, but also those are very close to the coastal zone could not be beneficiaries from fish and its products. In spite of the ample aquatic resource, fish consumption rate is almost negligible and these problems have enormous implications on the efficient and effective utilization of the fishery resources as well as the products. In addition, application of preservation methods such sun and sola tent drying is not practiced at all, which could help availabilities of fish during off seasons and play vital role in increasing fish consumption rate. ${ }^{5}$

\section{Fish in the diet}

Fish is one of the most important foods in human diet because of its high nutritional quality. It is rich in proteins of high nutritive quality as well as B vitamins. ${ }^{2}$ Small dried fish eaten with bones are good sources of calcium. The particular feature of fish is its content of cobalamin that is not available in plant foods. More-over, fish also includes n-3 fatty acids that are acknowledged to protect against cardiovascular diseases. Fish can therefore be a good substitute for pulses in cereal based diets of the poor. ${ }^{9}$ Fish is eaten in the fresh, dry, or processed form which includes breaded and battered products, quanta, cutlets, canned fish, fish pickles, fish soup powders, dry fish pickles and fish biscuit. ${ }^{8}$ Other value added fish products made from fish includes fish sandwich, fish paste, and fish noodles. ${ }^{5,8}$ Fish being a source of macronutrients, micro-nutrients as well as essential fatty acids, provide a significant complement to the mainly carbohydratebased diet of many poor consumer in the undeveloped countries. ${ }^{10}$ Fish like anchovy, sardine and mackerel are above all vital for nutrition for the reason that they are eaten whole along with the bones and are a source of minerals as well as other micronutrients. ${ }^{11}$

\section{Nutritional and health aspects of fish}

Fish is an important component of human diet. ${ }^{12}$ Fish and its product is high in many important nutrients, plus high-quality protein, iodine as well as diverse vitamins and minerals. Fatty types of fish are also high in omega-3 fatty acids as well as vitamin D. Proximate composition of fish exhibits strong inter-species and intra-species variations depending on different factors such as sex, age, season and fishing area. ${ }^{8,11}$

Fish carbohydrate: Carbohydrate is perceived at very low level (lower than 0.5 per cent). ${ }^{10}$ In fact, fish is a high-quality supply of all nutrients except for carbohydrates and vitamin $\mathrm{C}$. The carbohydrate in fish is present in the striated muscle as glycogen and as part of the chemical constituents of nucleotides. ${ }^{13}$

Fish protein: Protein which can be obtained from fish meat is simple to digest compared to other animal source protein. ${ }^{12}$ In average $60 \%$ of the world consumers from developing countries concerned on fish for more than $30 \%$ of their animal protein need. ${ }^{14}$ The most chief proximate composition of fish is protein; $15-23 \%$, that is the main and important source of energy $(80-90 \%)$. Protein that can be derived from fish contains appreciable biological content, that could be used as the crucial supply of protein in every people's diet. ${ }^{2}$ The amount of connective tissue found in the muscle of fish is relatively low plus it softens and dissolves more easily when cooked compared to the connective tissue of terrestrial muscle. Digestive enzymes available in the fish do not faced difficulties to breakdown its connective tissue and therefore are readily digested. ${ }^{9}$ Proteins of fish muscle holds adequate amounts of all necessary amino acids vital to the consumer's body for growth and maintenance of lean muscle tissue. A researcher suggests that fish protein recovers blood lipid profiles of humans and animals. Studies explain that low ratios of lysine to arginine and methionine to glycine in fish proteins could be involved in reducing plasma cholesterol absorption and may have a role as a cardio protective nutrient. $^{8}$

Fish lipids: Fish lipid is the most driving energy source from its compositions. It's content is highly dependent on several factors such as fish species, time of fishing and feeding habit. ${ }^{6}$ Lean fish, like cod fish, generally have between zero and two percent fat content whereas fatty fish, such as sardine, anchovies have sixteen per cent fat. The fat content of which is grew in ponds varies widely depending on the feed used. ${ }^{2,10}$ Fish contains largely polyunsaturated lipids, also called as PUFA, whereas saturated and monounsaturated lipids also available in low quantities. Amount of fat present in fish body parts are different. Some fish, such as cod or haddock, contain high fat content in their liver which is used to produce cod liver oil, an ample supply of the omega three long chain polyunsaturates and vitamins A and $\mathrm{D}$ in less amount. ${ }^{15}$

As far as research is concerned significance of fish towards human health is mostly obtained from long chain polyunsaturated fatty acids (omega-3). This importance is evident due to the key components of fish lipid, eicosapentaenoic acid (EPA) as well as docosahexaenoic acid (DHA). These two components of fish lipid play a crucial role in our health. One factor that influence the value of lipid is feed which is available in the natural environment. ${ }^{2}$ Aquatic brawn and red algae are the only form of life that can easily make long chain n-3 polyunsaturated fatty acids. Since fish feed on these aforementioned plants, they, in turn, become rich supply of these important n-3 fats. Even if other animals, as well as humans, can make long chain n-3 fats, most have complexity in making this and so advantage from intake these lipids as part of their normal diet. ${ }^{16}$

Studies have indicated that 1 or 2 servings of finfish per week significantly reduce the problem of various diseases related to heart. ${ }^{9}$ Adewuyi et al. ${ }^{9}$ have also reported that finfish consumers had $\leq 0.5$ the mortality rate of consumers who did not eat finfish. Results obtained in such case highlighted that higher rates of heart disease were recorded for men who ate no finfish at all compare to for men who ate finfish.

\section{Fish spoilage}

Generally fish as well as its products are very susceptible to spoilage in comparison to other type of foods. ${ }^{17}$ From the moment it is taken from the water a series of deteriorative changes start to occur. ${ }^{18}$ These changes occur rapidly and will eventually render the fish unfit for consumption. Chemical, enzymatic and microbial activities are three spoilage mechanisms of fish which can deteriorate its quality. Studies reported that in every year, about $20 \%$ of the gross fishery products are lost due to chemical deterioration and microbial spoilage. ${ }^{19}$ The largest lost is due to microbial activities that accounts one-fifth of the world's food supply and $30 \%$ of landed fish. ${ }^{20}$ Other studies stated that due to both enzymatic and microbial activities about 4-5 million tons of trawled and shrimp fish are lost every year. This is mainly because of improper onsite storage as well as improper preservation methods. ${ }^{19}$ 


\section{Mechanisms of fish spoilage}

Autolysis: The word autolysis means "self-digestion". ${ }^{20}$ Following death, the supply of oxygen to the tissues stops and energy production in the form of adenosine triphosphate (ATP) is no longer possible through normal (aerobic) respiration. The reservoir of creatine phosphate in the cells regenerates ATP only temporarily and becomes rapidly depleted. Alternatively, ATP is produced an aerobically by conversion of adenosine diphosphate (ADP) by the enzyme adenylate kinase. The third pathway by which ATP is produced is the anaerobic degradation of glycogen (Figure 1). The end product of anaerobic glycolysis is lactic acid which will accumulate in the muscle. The formation of lactate correlates well with the drop in post-mortem $\mathrm{pH}$ resulting from the hydrolysis of ATP. ${ }^{21}$ Reduction of $\mathrm{pH}$ can interfere with the structural properties of proteins and enzyme activities in fish muscle. As the post-mortem $\mathrm{pH}$ approaches the isoelectric point of muscle proteins, the water binding capacity of the muscle will be reduced affecting the fish's organoleptic quality. ${ }^{22}$ The $\mathrm{pH}$ drop leads to inactivation or reduced activity of enzymes adapted to near-neutral $\mathrm{pH}$ (e.g. glycolytic enzymes) while other enzymes with an acidic $\mathrm{pH}$ optimum will become more active. ${ }^{6}$ Well known examples of acidic active enzymes are the lysosomal proteases the cathepsins. Physical spoilage of fish such as color change, softening of fish flesh, increased incidence of fillet gaping, and increased activity of acidic proteases in fish muscle as well as decrease in protein stability is mainly due to change of $\mathrm{pH}$ which gives conducive environment for enzymes. ${ }^{8,23}$

With the cessation of ATP regeneration, the ATP concentration in the muscle continues to decrease after death and the nucleotides are catabolized to yield degradation products (Figure 1). The ADP formed from ATP is first degraded to adenosine monophosphate (AMP) by dephosphorylation. Deamination further degrades AMP to inosine monophosphate (IMP). ${ }^{24}$ The degradation of ATP to IMP via AMP is catalyzed entirely by endogenous enzymes. ${ }^{19}$ In the following degradation processes, IMP is decomposed to inosine and inosine is broken down to hypoxanthine by endogenous as well as bacterial enzymes. The organoleptic importance of nucleotide degradation is associated with the initial freshness loss, where the flavor of fresh seafood is lost as the flavor enhancer IMP is decomposed to the flavorless inosine. ${ }^{18}$ Later in storage, bitter off-flavor may develop at increased concentrations of hypoxanthine. ${ }^{8}$

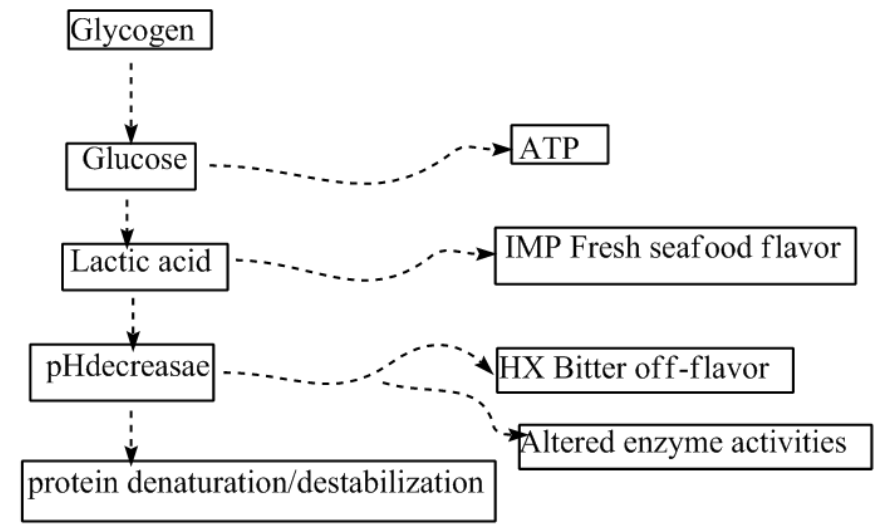

Figure I Post-mortem changes in fish muscle due to autolytic degradation. ATP, Adenosine triphosphate; IMP, inosine monophosphate; $\mathrm{Hx}$, hypoxanthine. Adapted from Green. ${ }^{23}$

Chemical spoilage/activities: Oxidation of fat is due to chemical activity. ${ }^{6}$ Fatty fish such as mackerel, oil sardine, grass carp, catla, trout etc., are more susceptible to chemical spoilage. The oil of fish becomes rancid after it comes in contact with oxygen as a result it develops off flavor as well ${ }^{2}$. Taste of fish muscle becomes strong tasted because the change of color of the fat and its viscosity ultimately the fish will be rejected by consumers. ${ }^{18}$ Antioxidants such as polyphenols as well as other viscous fluid and preventing from oxygen are some of the crucial prevention mechanism of fish rancidity due to chemical spoilage. ${ }^{13}$

Microbial action: Microbial spoilage is one type of fish spoilage mechanism that deteriorates fish quality by decomposing the flesh part. Gastrointestinal tract, body surface, gills are some of the place where microorganisms can found. ${ }^{17}$ In addition, unsanitary place, preservation equipments as well as processing materials are some of the conducive places for growth and proliferation. The most proximate composition which can easily degraded by microbial action of proteolytic organisms like Chromobacterium, Proteus, Pseudomonas, Halobacterium and Micrococcus are proteins which constituting about $70-90 \%{ }^{8,20}$ Carbohydrate fermenting microorganism such as Micrococcus, Leuconostoc, Streptococcus are responsible to spoil carbohydrate which available in small quantity compared to other proximate composition of fish (Figure 2). Lipids cover 3-5\% of fish flesh that is deteriorate by unique gram negative bacteria. ${ }^{20}$ Fish deterioration process can summarized as shown in Figure 2.
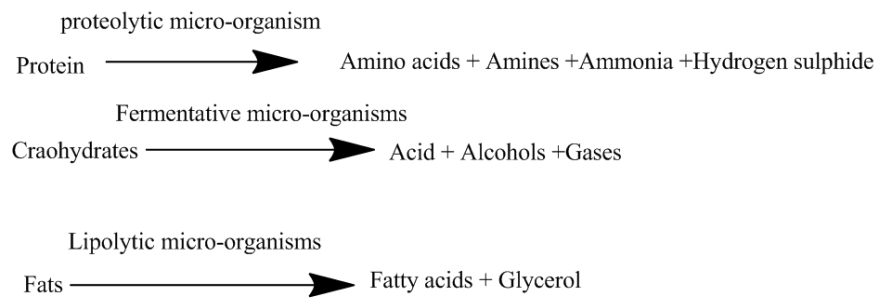

Figure 2 Fish deterioration process.

\section{The control of fish spoilage}

Fish spoil very quickly if they are not handled and treated properly. ${ }^{25}$ Understanding the reasons why fish deteriorate in quality and then become spoiled helps to formulate methods to overcome these factors. With this knowledge, techniques can be used to either preserve the freshness of fish, or treat fish by processing them into consumer products. ${ }^{2,12}$ Processed products have been treated in such a way, that they do not resemble the fresh raw material any longer. Such processing methods include canning, smoking, salting, drying, and to some extent freezing. ${ }^{26}$ Preservation is determinant not only for fish and its products but also other types of foods. Fishing areas, quantity of fish caught and farming location are some of the factors which can delay preservation. ${ }^{6,19}$ In such case delay of preservation can enhanced the chance of fish spoilage. When the fishes are caught in large quantities, greater than the amount of consumption, their preservation becomes a necessity for their future use. ${ }^{18}$ It would be good and convenient processing or market place to be very close to the fishing area to minimize such problems. ${ }^{12}$ Preservation and processing methods, overall become a very significant part of commercial fisheries and products. ${ }^{25}$ It is done in such a manner that the fishes remain fresh for a long time, with a minimum loss of odor, taste, flavor, nutritive value as well as the digestibility of their flesh. ${ }^{5-8}$

Drying: Removal of water using heat from a substance of food is known as drying. ${ }^{27}$ Significance of drying which can be implemented at the time of food drying includes heat transfer, causes water evaporation and mass transfer, removal of moisture from surface. 
These two things are primary and crucial once that should be overemphasis while drying fish. Fish and its products can be extended their shelf-life for long period of time so as to be available for consumers throughout the year via the application of preservation. Preservation has great potential to slow down and stopped microbial and chemical spoilage which are the main activities that deteriorate fish quality. ${ }^{17}$ However, drying time, drying type and drying season are very determinant factors to achieve the proposed goals. ${ }^{27}$ Constant drying rate and falling drying rate are the two periods of drying which exists during drying of food. ${ }^{28,29}$ Constant drying rate is characterized by the surface of the food being entirely saturated with moisture at the wet-bulb temperature of the air. ${ }^{5}$ Factors which control drying rate are temperature, air velocity, and the level of humidity. During the period of falling drying rate, the surface of the food/fish is already dry but the evaporation occurs inside the food. ${ }^{29}$ Now the air velocity has less effect and the speed of the drying process is largely reliant upon the resistance against the water vapor flow to the surface of the fish. Finally, the drying process stop completely and the moisture content of substance at that point is known as equilibrium humidity. ${ }^{8,30}$ Temperature and degree of humidity are the main factors which can influence equilibrium humidity. ${ }^{28}$

Water activity play great role in preservation of fish and other foods. ${ }^{31}$ Microbial activity as well as enzymes depend on water activity of the food. If water activity is high (more than 0.6 in dried food and 0.96 in fresh food) more than the permissible limit its easy for microorganism to degrade the fish flesh. ${ }^{27}$ Aquatic animals and their products are very susceptible to rapid microbial spoilage; therefore, sufficient care must be taken in drying fish as well as its products..$^{29}$ To produce safe dried fish products, temperature and pre treatment procedure (example salting) are the main aspects which can play vital role. Dry of fish at high humidity, low temperature or in shadow areas, increases the risk of microorganisms and may produce unsafe dried fish products. ${ }^{29,30}$

\section{Sardine and anchovies: small pelagic}

Pelagic fish range in size from small coastal forage fish to large apex predator oceanic fishes. They are usually agile swimmers with streamlined bodies, capable of sustained cruising on long-distance migrations. Sardine (Harengulap unctata) and anchovies (Thrissocles baleana, Amentum heteroboloum, and Stolephorus heterolobus) are some of the small pelagic fish abundantly available (about 50,000 tons/year) in Eritrean Red sea waters., ${ }^{4,53}$ Due to the high temperature and availability of feed these fish have special fishing season which is from September to May, however sometimes fishing season extends until June. Offshore schools never came into reach of the beach seines. Some anchovy that are larger in size were never reported to reach north of Shumaisland therefore the main fishing area for this fishery remained the Assab area where many Massawa dhows navigated during the season. ${ }^{32}$

Nutritional composition of white bait-anchovies: The moisture, protein, fat and ash content of stolephorus spp. are $79 \%, 15.1 \%$, $1.3 \%$ and $2.6 \%{ }^{8}$. In most species, the omega- 3 polyunsaturated fatty acid content varied from 20 to 30 percent. The fatty acids recorded in Stolephorus indicus, Indian anchovy was 30.9 percent. Anchovies have a much lower fat content than sardines or herring as shown in Table 1.

\section{History review and current utilization}

The Eritrean marine fisheries of 30 to 40 years ago have been stated in some detail by earlier studies. In the past fishing activities were very active. In 1954 over 25,000 tons/year of fish catches were reported, before to the pulling out of Yemeni fishing units., ${ }^{4,33}$ Out of 25,000 tons small pelagic fish (such as anchovy and sardine) accounted over $80 \%$. These catches were processed into animal feed (fishmeal) or sundried in Massawa for export to Far East markets as well as European. ${ }^{1}$ Tsighe et al. ${ }^{6}$ also reported that in Eritrea, where fish can be abundantly found, the small pelagic fish of Eritrean Red Sea waters account for about $60 \%$ of the total maximum sustainable yield of marine fish resources, but their utilization for human consumption is minimal. Indeed, these fish are largely incorporated into animal feed rather than human use. Over 5700 tons of processed fish products were exported in 1966-1967. However, these energetic fishing activities were declined into 4,000 metric tons in 1972, due to growing internal warfare as well as successive instability. ${ }^{1}$ This trend sustained during the following years. Several fishing craft were damaged and, without outlet for their production, local fishers increasingly turned to other activities or other countries. As a consequence, by the end of the 70th, the fisheries in Eritrea had entirely buckled. ${ }^{34}$ After independence in 1991, the fisheries sector of Eritrea revived and the artisanal fish landings attained its apex in 2002 with yearly catch of $2,130 \mathrm{mt}^{3,4}$ It was reported that the capture production was recovered slowly since then and the latest maximum sustainable yield was 4000 tons in $2013 .{ }^{1}$ The catch level of small pelagic, mainly anchovies and sardines from 1993 to 2011 were $50,000 \mathrm{mt}$ which represent the majority of the potential yield followed by demersal species 18000 tons per year and larger pelagic species 50000 tons per year. ${ }^{1,33}$ After 2013, there is no up-to-date information concerning the catch level of fishery resources due to the luck of recent research (Table 2).

Table I Fat content of specific fish ${ }^{32}$

\begin{tabular}{ll}
\hline Fish & Fat percent \\
\hline Anchovies & $0.84-2.33$ \\
Herring & $4.80-15.42$ \\
Sardine & $0.07-11.81$
\end{tabular}

Table 2 Mid-1960s export level of Eritrean marine commodities ${ }^{32}$

\begin{tabular}{lll}
\hline Commodity & Quality (tons) & Values (\$) \\
\hline Fishmeal & 1430 & 459585 \\
Dry fish & 3422 & 2080408 \\
Fresh fish & 702 & 237073 \\
Shell products & 213 & 125286 \\
Other products & 1589 & 37829 \\
Total & 7356 & $2940 \mathrm{I} 8 \mathrm{I}$
\end{tabular}

\section{Dried fish}

Ismai $^{35}$ indicated that drying of fish and fish products was an important method of fish preservation for most dried in open air system need to be covered or stored at the end of each day and uncovered. Kofi ${ }^{36}$ said "sun drying as well as salting were used jointly to preserve fish in West Africa. The process is always combined by fish enzymes and impart characteristic stinky odor the process". Cooking and other processing methods have an effect on nutritional contents of various fish species. Afolabi et al ${ }^{37}$ have been studied the organoleptic as well as nutritive changes of Nigerian traditionallyprocessed freshwater fishes. Herrick ${ }^{38}$ indicated that, the main reason for drying was reducing moisture content, so that the food stuff 
may be stored safely for long periods. Graw ${ }^{39}$ stated that, drying in food is aimed to guarantee constancy of product safety and quality for specific period of time that will ensure product accessibility on off seasons to consumer so that they can be beneficiaries from the valuable nutritional content of fish and its products throughout the year. Tropical countries use spreading type of sun drying method to enhance evaporation of moisture from the muscle surface. While hung up fish to dry by wind is common in temperate countries, such drying process takes longer time compared to sun drying, however fish has longer shelf-life this could be due to lower ambient temperature. ${ }^{40}$ Nketsia et al. ${ }^{41}$ studied the effect of drying methods, salting methods and time on the quality of salted dried tilapia sp. fish. They found that all the three variables had significant effect. Dried fish products are susceptible to mould spoilage rather than bacterial spoilage. ${ }^{42}$ Open sun drying has some limitation such as longer drying time, depend on weather conditions, venerable to dusts, rain and insect infestation. Therefore, such factors provide suitable environment for bacteria to spoilage the fish. ${ }^{3}$

Solar drying: Solar drying is a safe and fast way of drying fish and other type of foods using sunlight. It is different from open direct sun drying in a way that heat is trapped inside a tent or box, this trapped high temperature is used to dry the fish in short period of time. ${ }^{27}$ Solar tent dried products are safe with excellent quality. Since such type of driers are covered with plastic sheets, wire mesh and wooden frames which can be bought from local market with few amount of money (such drier needs low investment). Therefore, the value addition to the produce could result in a better quality and yield good profit compared to the produce of open sun dried. ${ }^{28,43}$ The final solar tent dried fish product has a long shelf life, which could supply protein, minerals as well as vitamins when the fresh fish themselves may not be available in offseason. ${ }^{44}$ More-over, easy to handle and pack, making storage, marketing and much easier transportation are some of the great advantage of dried products. In Asian countries, dried fish and its products are very popular, people are enjoying and even exporting to some other countries for hard currency. ${ }^{45}$ Solar dryers are affordable technology as a result which has been developed and tested around the world. Plastic or class materials are the most referable and cost effective to use while design which can increase internal temperature of the air around the food or fish intended to dry, so as to accelerate drying. ${ }^{44}$ To compare quality of dried fish a research has been conducted on three solar dryers as well as open sun drying. Fish was placed on black volcanic rocks in order to raise the temperature. ${ }^{46}$ Based on the result obtained from panelists, fish dried by the three solar dryers had higher quality than fish dried in direct sun dryers. Therefore, solar dryers are more effective than direct sun drying. ${ }^{5,46}$ Raw materials used to construct dryers has some contribution on the cost which can affect the final price of the dried fish product. A solar cabinet dryer made from clear and black polythene sheet stretched over a wooden frame was slightly expensive than the solar tent dryers. ${ }^{47,48}$ In Yemen and Gambia solar dryer (about one tone capacity) has been constructed using horticultural green house and successful results has been obtained. ${ }^{49}$ Some dryers which depend on natural convection could denature protein of dried fish as a result of very high temperature $\left(\geq 40^{\circ} \mathrm{C}\right)$. Therefore, controlling air temperature in agro-waste dryers is very necessary so as consumer could get the full nutritional content of dried fish product. ${ }^{50}$ In Thailand solar dryers are effectively used to dry varieties of aquatic animals such as squid..$^{51}$ In addition report has been indicated that mould growth are effectively prevented using gamma radiation. Squid dried using a combination of irradiation as well as sorbet dip has been successful stored more than 6 months. ${ }^{52}$ A product which called seasonal dry squid is very famous in Japan and has got great acceptability by the rest of the world. ${ }^{52}$ Some pretreatments are very necessary to be taken before drying such as dressing, skinning, boiling, seasoning, smoking, and cutting, seasoning a second time, at the end the product should be dried and packaged..$^{53}$

\section{Evaluation of freshness quality of fish products}

Fishes are highly perishable. ${ }^{6}$ Spoilage of fish is due to autolytic and microbial reactions. Natural enzymes present in the tissues of the fish retain much of their activity after the death of the fish and continue to operate although changes are mostly catabolic. ${ }^{31}$ The rates at which these reactions are produced depend on temperature, type of fish and time period. The freshness quality of fish and fish products can therefore be understood by periodically assessing the biochemical, microbial and sensory qualities. ${ }^{8}$

\section{Biochemical evaluation}

Protein and fat in fish undergo changes during processing like drying, freeze drying, canning etc. and during storage. ${ }^{8}$

\section{Changes in fish protein}

Total Volatile Base Nitrogen (TVBN): TVBN is one of the most commonly used to assess quality aquatic foods. Microbiological spoilage of sea food causes the formation of volatile bases such as ammonia, dimethylamine and Trimethylamine. ${ }^{8,20}$ The measurement of these compounds is an indirect method of assessment of freshness quality of sea food. This method is not capable of identifying the early stages of deterioration because total volatile base nitrogen values are not linearly related to the length of time (days) if the fish being assessed was kept in ice and it cannot be used to envisage the shelf-life of that fish. ${ }^{29}$ However, these values are useful for assessing quality during later stages of storage and therefore can be routinely used as a standard method for assessing the quality changes in chilled, frozen, dried and canned seafood. ${ }^{54}$ The maximum admissible limit of total volatile base nitrogen for fish and fish products are presented in Table 3.

Table 3 Levels of TVB-N in fish and fishery products ${ }^{54}$

\begin{tabular}{ll}
\hline Items & Maximum admissible limy \\
\hline Fresh fish & $35-40 \mathrm{mg} / 100 \mathrm{~g}$ \\
Frozen fish & Not greater than $30 \mathrm{mg} / 100 \mathrm{~g}$ \\
Salted and sun dried fish & Within $100-200 \mathrm{mg} / 100 \mathrm{~g}$ \\
Canned sea food & Not greater than $20 \mathrm{mg} / 100 \mathrm{~g}$ \\
\hline
\end{tabular}

Changes in fish lipids: Two types of changes take place in the lipids during processing and preservation of fish. ${ }^{2}$ They are hydrolytic changes and oxidative changes. Both these changes reduce the organoleptic quality and shelf life of fish products. These changes result in rancidity. ${ }^{8}$

Lipid hydrolysis: In a living system, enzymes, hormones etc, regulate the break down and biosynthesis of lipids. When the organism dies, the changes become uncontrolled, leading to breakdown of tissue constituents, lipids, protein etc. producing undesirable breakdown products. Lipases bring about hydrolysis of lipids producing Free Fatty Acids (FFA) resulting in hydrolytic rancidity. ${ }^{8,19,20,27}$

Lipid oxidation: Lipid oxidation is a severe difficulty in fatty fish of highly unsaturated nature. ${ }^{6}$ The double bonds of unsaturated fatty acids are very vulnerable to oxidation as a result various carbonyl 
and other secondary oxidation products are produced. Besides producing off-flavors, they reduce the shelf life and nutritional value of the product. ${ }^{19}$ Some of them are toxic in nature. Peroxides, hydroperoxides, aldehydes, ketons, etc., are the types of products produced by the oxidation of the fatty acids. These reactions are initiated by free radicals generated from unsaturated bonds which start chain reactions resulting in the production of various undesirable compounds mentioned here. Finally the free radicals form nonradical polymers which terminate the chain reaction. Oxidized lipids interact with proteins reducing the nutritive value of the proteins considerably. ${ }^{8,20}$ The rate lipid oxidation in fish and its products can be slow or fast depending some parameters such as oxygen content, type of substrate (fatty acid), extent of reaction, UV light, enzyme activity, temperature, moisture content, presence of metals, protein content, presence of antioxidants, free amino acid content as well as other chemical reactions. All these factors play significant role in the rate of oxidation, however, moisture is the most determinant amongst all. ${ }^{19,20}$

Free fatty acid (FFA): FFA's are formed as a result of lipid hydrolysis and it may be brought about by microbial or endogenous lipases. ${ }^{2,6}$ Hydrolysis splits the triglycerides into glycerol and FFA. Frankel ${ }^{55}$ has reported that the accumulation of FFA increased with prolonged storage time and at elevated frozen storage temperatures. During frozen storage of fish, the formation of FFA is rapid initially followed by a much slower rate. The FFA value is an sign of the degree of hydrolytic rancidity. Free fatty acid value is evaluated by titration with a standard alkali. ${ }^{8}$ The tolerable limit for FFA in seafood is about $0.5-$ $1.5 \%{ }^{13}$

Microbiological evaluation: Fish spoilage denotes the disruption of the original quality attributes such flavor, texture as well as nutritional content of the food. The food becomes unsuitable for human consumption. ${ }^{8}$ Because of the changes in sensory quality attributes, like off flavor, bad taste and unusual color from the original quality attributes any food and its products became unsuitable for consumption. This happens as a metabolic process inside the food. ${ }^{19,20,23,27}$ When a fish is a life its immune system is resistant to any microbial activities. However, after the fish is caught from the sea, the immune system start to collapse, then bacteria can enter via many parts such as gill, skin, in to blood vessels and belly cavity. ${ }^{17}$ After they get favorable condition they start to grow and multiply rapidly and decompose its flesh and ultimately deteriorate its quality, producing off odors and off flavors. ${ }^{20,27}$

Water activity $\left(\mathrm{a}_{\mathrm{w}}\right)$ : Water activity $\left(\mathrm{a}_{\mathrm{w}}\right)$ is an essential parameter which is help full to assess food storage life and safety with respect to physical properties, rates of deteriorative reactions as well as microbial growth. ${ }^{31} \mathrm{~A}_{\mathrm{w}}$ is the partial vapor pressure of water in a substance divided by the standard state partial vapor pressure of water. It has vital role in growth of microorganisms and chemical and biochemical reactions as solvent when available more than the allowable limits. ${ }^{56}$ Water activity is a vital feature affecting the shelf-life dry and dehydrated fish and its products at any condition. Dried fish and its dehydrated products has great recognition among today's consumers and traders. ${ }^{57}$ The food stability in terms of rates of degradative reactions can be expressed as a function of $a_{w}$. The reason that aw is important in the study of cured and dried fish is that all living things rely on water for growth and survival. ${ }^{20} \mathrm{~A}$ low value for aw in dried and cured products means that water is denied to micro-organisms and other spoilage factors. Lowering the $\mathrm{a}_{\mathrm{w}}$ below about 0.9 is sufficient to prevent the growth of the dangerous toxin forming pathogenic bacteria. When aw is below 0.63 , molds will fail to germinate and grow. ${ }^{8,20}$
Sensory evaluation: Sensory evaluation is a scientific discipline that applies principles of experimental design and statistical analysis to the use of human senses (sight, smell, taste, touch and hearing) for the purposes of evaluating consumer products. ${ }^{52}$ Sensory analysis is used to answer questions about product quality, questions relating to discrimination, description and preference. Discrimination is of particular relevance in the context of product quality control, in shelf life studies and in investigation of possible taints. ${ }^{8,29}$ Descriptive tests are more appropriate in the product development context, where there is a desire to develop a product that matches a known target quality or to reformulate an existing product using different ingredients or processes or to investigate the differences among a range of experimental and or commercial products. ${ }^{18}$ Preference and acceptability tests are aimed at establishing whether product differences are recognized by the consumer and are seen to be improving liking or acceptability. ${ }^{52}$ These methods lie on the fringe between sensory analysis and consumer research and have different panel recruitment criteria from those for discrimination or descriptive tests. These assessors need to be representative of the target consumer population and preferably to have little or no sensory training. ${ }^{58}$ Appearance is very important in food perception. If a product does not have an appearance that is visually acceptable (as compared with previous images stored in the memory), a person may decide not to eat the food. Visual appraisal can have a significant effect on the other senses. ${ }^{8,58}$ The appearance of food contributes immeasurably to one's esthetic appreciation of them. ${ }^{59}$ Flavor is the amalgamation of odor as well as taste. Factors that can affect flavor of food are cold, heat, tactile sensations, and sensations of pain. ${ }^{8}$ From the sensorial point of view, flavor has a key role in evaluating the acceptance of all type of dried as well as fresh wet food and as with texture, it is a dynamic process as changes in intensity occurs over time. ${ }^{18}$ The human sense of smell can sense various different odors when sniffed via the nose, but is also important for perceiving volatiles given off by food items in the mouth as part of the flavor perception. The sense of smell is an important input to sensory evaluation of a food. ${ }^{5,8,20}$ Texture has an imperative role in the overall acceptance not only to seafood but also to agricultural foods. Consumers expect certain products to have a particular texture. Texture is therefore one of the major criteria used by consumers to assess the quality and freshness of foods. ${ }^{59}$ Texture, from the sensory stand point refers to the sense of feel of food in the mouth. Words of texture are crisp, hard, soft and chewy. ${ }^{8,59}$ Crispiness of food contributes to the pleasure derived from eating them. The texture of food is important not only per say but also because of the effect of texture on taste. The appearance, odor, mouth feel and taste influence the overall acceptability of food. Even though appearance, odor and taste are acceptable, a food may be rejected on the basis of mouth feel. ${ }^{58}$

\section{Conclusion}

The high quality protein, ample essential amino acids as well as an excellent source of vitamin B complex makes fish and its products as a high nutritional value. They are also very susceptible to spoilage which starts to deteriorate within short period of time. To extend the period of fish availability whereby people can utilize effectively and efficiently once fish is preserved at the right time and by reliable and convenient method of preservation that people can afford it. As the country has ample resource of small pelagic fish, consumption rate could be increased once consumer has awareness on nutritional and health aspect of fish and fish products. Sensory attributes also play vital role in the overall acceptance of a product. Small pelagic fish such as anchovies, sardine, mackerel and herring are eaten in the fresh, dry, or 
processed form of various value added products or functional foods, which includes breaded and battered products, quanta, cutlets, canned fish, fish pickles, fish soup powders, dry fish pickles and fish biscuit.

\section{Acknowledgements}

The authors would like to thank the Eritrean Research Fund and Dr. Zekeria Abdelkerim, Dean, Massawa College of Marine Science and Technology (MCOMSAT) as well as staff members of Marine Food and Biotechnology, MCOMSAT for their upkeep and encouragement.

\section{Conflicts of interest}

Author declares that there is none of the conflicts.

\section{References}

1. FAO Fishery and Aquaculture Development Country Profile-The State of Eritrea. 2015.

2. Pal J, Shukla B, Maurya A, et al. A review on role of fish in human nutrient with special emphasis to essential fatty acid. International Journal of Fisheries and Aquatic studies. 2018;6(2):427-430.

3. IFAD. Project Design Report (Report N0. 2294 ER), Fisher Development Project, Eastern and Southern Africa Division Programme Management Department. Asmara, Eritrea. 2010.

4. Araya TM, Krishnan M. Performance, Potential and Prospects of Fisheries Sector in Eritrea. IIFET Tanzania Proceedings. 2012. p. 1-6.

5. Abraha B, Samuel M, Mohammud A, et al. A comparative study on quality of dried anchovy (Stelophorus heterolobus) using open sun rack and solar tent drying methods. Turk J of Fish and Aqu Sci. 2017;17:11071115 .

6. Tsighe N, Wawire M, Bereket A, et al. Physicochemical and microbiological characteristics of fresh Indian mackerel, spotted sardine and yellowtail scad, from Eritrea Red Sea waters. Journal of Food Composition and Analysis. 2018;70:98-104.

7. Sankar TV, Anandan R, Suseela Mathew. Chemical composition and nutritional value of anchovy (stolephorus commersonii) caught from Kerala coast. India. 2013.

8. Gram L, Dalgaard P. Fish spoilage bacteria-problems and solutions. Current Opinion in Biotechnology. 2002;13(3):262-266.

9. Adewuyi SA, Philip BB, Ayinde IA, et al. Analysis of profitability of fish farming in Ogun State, Nigeria. J Hum Ecol. 2010;31(3):179-184.

10. Abbey A, Amengor M, Atikpo M, et al. Nutrient content of fish powder from low value of fish and fish products. Food Science and Nutrition. 2016;5(3):374-379.

11. Food and Agriculture Organization FAO. FAO workshop on fish technology, utilization and quality assurance. Bagamoyo, United Republic of Tanzania. 2005.

12. Mohanty BP. Fish as Health Food. In: Handbook of Fisheries and Aquaculture. 2nd ed. ICAR-DKMA. 2011. p. 843-861.

13. AOAC Official Methods of Analysis. 8th ed. Association of Official Analytical Chemists, Maryland, USA. 2000.

14. Pauly Idakwa, Mamudu H. Proximate composition and acceptability of Bubyi: A traditional fermented soar tent dried fish condiment. Department of food science and technology. Nigeria: University of Maaiduguri; 2016.

15. Nur AM, Jamaludin M. Fatty acid composition of selected Malaysian fishes. Sains Malaysiana. 2012;41(1):23-40.

16. Eyo AA. Fish processing in the tropics. National Institute for Fresh Water Fisheries Research. Nigeria: NIFFR, University of Ilorin Press, New Bussa; 2001. 403 p.
17. Gram L, Huss H. Microbial spoilage of fish and fish products. Journal of Food Microbiology. 1996;33(1):121-137.

18. Solanki J, Parmar H, Parmar A, et al. Freshness evaluation of fish by quality index method (QIM) and instrumental method at veraval fish landing centre. International Journal of Processing and Post Harvest Technology. 2016;42-46.

19. Ghaly AE, Dave D, Budge S, et al. Fish Spoilage Mechanism and Preservation Techniques: Review. American Journal of Applied Sciences. 2010;7(7):859-877.

20. Huss HH. Fresh Fish -Quality and Quality Changes. Italy: Food and Agriculture Organization of the United Nations; 1995.

21. Foegedin EA, Lanier TC, Hultin HO. Characteristics of edible muscle tissues. In: Fennema OR editor. Food Chemistry. USA: Marcel Dekker, Inc; 1996. p. 879-942.

22. Lawrie RA, Ledward D. Lawrie's Meat Science. 7th ed. UK: Woodhead Publishing; 2006. 464 p.

23. Green DP. Sensory evaluation of fish freshness and eating qualities. In: Alasalvar C, Greenhoff K, MacFie HJ editors. Handbook of Seafood Quality, Safety and Health Applications. 2010.

24. Hong H, Regenstein J, Luo Y. The importance of ATP-related compounds for freshness and flavor of post-mortem fish and shellfish muscle: A review. Crit Rev Food Sci Nutr. 2017;57(9):1787-1798.

25. Rawat S. Microorganisms and their prevention. Asian Journal of Plan Science and Research. 2015;5(4):47-56.

26. Kader AA. Increasing food availability by reducing postharvest losses of fresh produce. Acta Horticulturae. 2005;3:2169-2176.

27. Immaculate J, Sinduja P, Jamila P. Biochemical and Microbial qualities of Sardinella fimbiata Sun dried in different methods. International Food Research Journal. 2012;19(4):1699-1703.

28. Sigurjon A. The Drying Fish and Utilization of Geothermal Energy-The Iceland Experience. CHG Bulletin. 2003. p. 1-7.

29. Rahman MS, Guizani N, AL-Ruzeiki MH. D-and Zvalues of microflora in tuna mince during moist-and dry-heating. Lebensmittel-wissenschaft and Technologie. 2004;37(1): 93-98.

30. Doe PE. Hand book of Drying processes. USA: Marcel Dekker; 2003. p. 584-594.

31. Modibbo U, Osemeahon S, Shagal M, et al. Effect of moisture content on the drying rate using traditional open sun and shade drying of fish from Njuwa Lake in North-Eastern Nigeria. IOSR Journal of Applied Chemistry. 2014;7(1):41-45.

32. Grofit E. The Red Sea fisheries of Ethiopia. Centre for Agricultural Cooperation with Developing Countries, Ministry of Agriculture, State of Israel. 1971.

33. Pasience PM. Overview of Eritrean Fishery Sector. National Agricultural and Pilot Fishery Programme, Massawa, Eritrea. 2009.

34. Breuil C. Fish handling, distribution, and marketing in Ethiopia. Report prepared for the Project TCP/ETH/0052. Italy: Assistance to Fisheries Planning, Management, and Development; 1990.

35. Ismail N, Wootton M. Fish Salting and Drying a review. ASSEAN Food Journal. 1982;74:175-183.

36. Kofi ME. Fermented Fish in Africa. A Study on Processing Marketing and Consumption. FAO Fisheries Technical Paper. 1992. 80 p.

37. Afolabi AO, Adesulu EA, Oke OL. Polynuclear aromatic hydrocarbons in some Nigerian preserved freshwater fish species. J Agric Food chemistry. 1983;31(5):1083-1090.

38. Herrick O. Circulation of Air in Natural Convection Solar Dryer. Journal of Agriculture Engineering Research. 1985. p. 65-70. 
39. Graw CR, Williams MA. Fish Meals as Amino acids Source. Food Technology. 1985;810-817.

40. Food and Agriculture Organization FAO. The production of fish meal and oil. Fisheries Technical paper.142. 1986.

41. Nketsia J, Tabiri O, Sefa-dedeh. Quality Attributes and Utilization of Cured Fish in Ghana. Journal of Applied Science \& Technology (JAST). 2000;5(1\&2):148-155.

42. Jan P, Nedyalka Y, Micheal G. Antioxidants in food. UK: Wood heat Publishing Limited; 2001. p. 421-450.

43. Doe PE. Polyethylene tent Dryer for improved Sun drying of fish. Food technology in Australia. 1977;29:437-441.

44. Olokor O, Omojowo S. Adaptation and improvement of a simple solar tent dryer to enhance fish drying. Nature and science. 2009;7(10):18-24.

45. Food and Agriculture Organization FAO. The prevention of losses in cured fish. Italy: FAO Fisheries Technical Paper 219; 1981. 87 p.

46. Trim DS, Curran CA. Comparative study solar and sun drying in Ecuador. AGRIS. 1983; 44 p.

47. Doe PE. How to make a solar cabinet dryer for agricultural products. Canada: McGill University; 1973. 8 p.

48. Excell RH, Kornsakoo S. Low cost solar rice dryer. Appropriate Technology. 1978;5(1):23-40.

49. Sachithananthan K,Trim D S, Sperirs CI. Proc FAO Expert Consultation on Fish Technology in Africa. Italy: FAO Fisheries No. 329. 1986. 161 p.

50. Clucas IJ. Present fish drying techniques in Zambia and suggested improvements. A report prepared for fisheries development project. In: Ojutiku RO, Kolo RJ, Mohammed ML editors. Aquaculture and Fisheries Technology. Nigeria: Federal University of Technology; 1982. $25 \mathrm{p}$.
51. Akonor PT, Ofori H, Dziedzoave NT, et al. Drying characteristics and physical and nutritional properties of shrimp meat as affected by different traditional drying techniques. International Journal of Food Science. 2016;1-5.

52. Yoon Y, Cho W, Park J, et al. Effect of Gamma irradiation on shelf-life extension and sensory characteristics of Dak-gablbi (Marinated diced chicken) during accelerated storage. Korean J Food Sci Ani Resour. 2009;29(5): 573-578.

53. Doe PE, Olley JN, Haard NF, et al. Methodology for quality measurements in fish smoking and drying production and quality. USA: Technomic Publishing Company. 1998;5:117-135.

54. Prasad MM, Raoccp. Storage studies of dry salt cured fish with special reference to discoloration. Fish Technology. 1994;31:75-78.

55. Frankel EN. Lipid Oxidation. 2ed. England: The Oily Press; 2005. p. 20-56.

56. Rillo BO, Magal RP, Migual MM, et al. Microbiological quality of dried salted mackerel (Rastrelliger branchyosomus). In: Maneepun S, Varangoon P, Pithakpol B, editors. Food Science and Technology Industrial Developments. India: Institute of Food Research and Products Developments; 1998.

57. Mukharjee S, Bondyapadhya S, Bose AN. An improved solar dryer for fish drying in the coastal belt. J Food Sci Tech. 1990;27:175-177.

58. Oehlenschlanger J. Sensory evaluation in inspection. In: Proceeding of the final meeting of the concerted action evaluation of fish freshness, Institute International du Froid. 1998. p. 363-368.

59. Olafsdottir GE, Martinsdottir P, Dalgaard B, et al. Method to evaluate fish freshness in research and industry. J Trend Food Sci Technol. 1997;8(8):258-265. 